\title{
The Prospective Of The Development Of Ecotourism In Jizzakh Region
}

\author{
M.R.Usmanov \\ Jizzakh State Pedagogical Institute
}

\begin{abstract}
This article is devoted to the issues of development of ecotourism in Jizzakh and provided with information about ecological tourism, travel, route and districts that are protected by government.
\end{abstract}

Ker

EY WORDS: Ecotourism, ecotravel, cultural heritage, ecological culture, the places for piligramage, reserves, local tourism.

\section{NTRODUCTION}

We know that today ecotourism is not only seen as a separate line of science, culture, nature conservation, but also improving the lives of local people, providing them with jobs, as well as to instill in the minds of our youth a sense of pride in their environment and national pride.

Here it should be noted that in the Address of the President of the Republic of Uzbekistan to the Oliy Majlis on the most important priorities for 2019, the task was given as ". ..we must take comprehensive measures to develop tourism, attract as much as investments in the sector and increase human resources. In our country, tourism is firmly limited to our ancient cities, historical and cultural monuments. However, the unique nature of our country, national reserves, there is a great potential for the development of tourism in these areas. Particularly, the development of medical tourism, pilgrimage tourism and ecotourism will give a great impetus not only to the development of the economy, but also the social sphere".

To add to it, in order to accelerate the development of this sector, we can prove the Decree of the President of the Republic of Uzbekistan No PD-5611 "On measures to accelerate the development of tourism in the Republic of Uzbekistan", which was dated on January 5, 2019. This decree defines the target parameters for the construction of the hotels in the Republic of Uzbekistan in 2019-2021, promising investment projects, cultural facilities and institutions for the application of modern information technologies.

Main body. New resources of Uzbekistan for ecotourism are the plains, mountains and water basins of our country. In terms of ecotourism opportunities, Jizzakh region is one of the leading ecotourism regions not only in Uzbekistan, but also in Central Asia. Many types of tourism in the region, particularly, historical, architectural and archeological monuments, historical recreational purposes, religious sites, places of pilgrimage and unique cultural and ethnographic traditions are the treasures of tourism in the region. But so far, touristic opportunities in most districts of the provinces are not being used. This requires a comprehensive study and planning of the geography of tourism in the region, as well as the development of clear criteria.

In terms of ecotourism opportunities, Jizzakh region is one of the leading touristic regions not only in Uzbekistan, but also in Central Asia. It would be expedient to attract the world tourists on ecotourism in Bakhmal, Zaamin, Forish, Gallaaral, Yangiabad districts, which have a special place with the unique beauty and unique nature of the Jizzakh oasis, as well as the ancient history of our people.

Globally, in recent years, ecotourism has become one 
of the most promising areas of tourism. The share of ecotourism in the total share of tourism exceeded $12 \%$. One of the main reasons for this is that traveling to nature brings peace and quietness to man. For this reason, the demand for travelling to natural sites in the global tourism industry is growing day by day. Ecotourism can include objects created by nature, such as miracles, rocks, waterfalls, springs, lakes, caves, rare plants, forests, and even ancient monuments left by humans in nature. Eco-travel is a unique pleasure, on the other hand, it creates opportunities for profit: increases foreign exchange earnings, develops infrastructure and creates many new jobs.

For the regional organization and development of, in our opinion, we recommend the classification of the development of promising routes in the following areas:

- plain eco-route (around the Aydar-Arnasay lake system-Jizzakh-Aydar-Arnasay eco-route);

- foothills (springs, caves - Jizzakh-Forish, JizzakhGallaorol eco-route);

- -mountainous areas (nature reserves and national park, Bakhmal and Zaamin, Nurata-JizzakhBakhmal-Zaamin, Jizzakh-Nurata eco-routes) and others.

It is known that in accordance with the Law of the Republic of Uzbekistan "On Protected Natural Areas" protected natural areas are divided into state and order reserves, nature parks, state natural monuments, forestry, hunting farms, resort areas. They are important for their unique ecosystem, fauna and flora, as well as their cultural monuments.

In Jizzakh region, 372 cultural heritage sites are under state protection. 42 of them are historical monuments, 267 are ecological sites, 63 are monumental ones. One of the urgent issues is to reconsider and repair all of this as an ecotourism destination. The location of Zaamin State Reserve, Nurata State Reserve, Zaamin National Park in the region is important for the prospects of ecotourism. Ecotourism, by its content and essence, is the journey of people from their place of residence to another natural object (place and space) with a specific purpose (or rather ecological). Travelling of the individuals to the habitat of living organisms (including humans) is an ecological trip to the environment or to certain natural objects for the purpose of recreation, sports, health, enlightenment or other purposes.

Today, the natural areas, which are protected, are the major links in eco-tourism. In recent years, legislation, which has been adopted, provides wide range of opportunities for ecotourism and the creation of new national parks in the 291 protected areas and adjacent areas, which is the evidence of the state's focus on environmental protection and conservation of flora and fauna. organize ecologically clean and very close to nature recreation in natural areas of the region, which is one of the current issues. Existence of many places with health-improving properties of the human body, wellstudied national natural park with the presence of unique natural, historical and cultural tourist sites, biological, ecological state reserves, are the support of tourism by local and regional leaders and the population's confidence to the future of tourism.

Opportunities: possibility to form an organization which is responsible for infrastructure, taking full responsibility, the formation of a body that approaches tourism from a professional point of view, the availability of hospitality and high-quality services to visitors, cooperation with local authorities and tourism officials, as well as local and private ones acts to fully explore the fact that the staff of the regions have at least a little knowledge and skills in the field of touristic services are being done.

\section{ONCLUSION}

In short, it is necessary to establish branches of the regional tourism department in areas where tourism can be developed. It is necessary to invite tourism volunteers from developed countries to the tourism departments of the regions, to organize trainings for employees of the regional tourism department and specially protected areas in developed countries in the field of tourism. In order to create the material base of regional tourism and to raise sufficient funds for the reconstruction of tourist destinations, the development and promotion of tourist routes, should establish funds by existing enterprises and organizations, trade unions in the region. It is necessary to organize various events and special sports competitions dedicated to the reconstruction and preservation of existing archeological and natural monuments in the region. Together with the existing artisans' association, folklore groups, museums and kitchens in the region, tourism fairs should be organized dedicated to different fields of the tourism.

To conclude, it should be noted that for the development of ecotourism in the region, it is important to pay attention to the following issues:

- development of a national model of Jizzakh ecotourism, which is a unique "brand" of the organization and development of tourism in the region;

- $\quad$ touristic zoning of existing ecotourism routes;

- geographical analysis of the ecotourism potential of each district;

- strengthening the training and retraining of ecotourism specialists;

- the use of foreign experience in the development of tourism in the territorial organization of domestic and international tourist routes, etc. 


\section{EFERENCES}

1. Decree of the Republic of Uzbekistan "On measures to ensure the accelerated development of tourism", 2017

2. [Khoshimov M."Ecological tourism of Uzbekistan".Samarkand.2012

3. Nigmatov A., Shomuratova N."'Ecological tourism a new field of science // Ecology Bulletin".2003. Issue 6. 14 -17-p.

4. Brodsky A.A."Nature protection in Turkistan". Toshkent.1993

5. Shomuratova N.T."Stages of development of ecotourism"// International scientific-practical conference.Andijan.2007.96-p.

6. http://www.eco-tourism.uz/

7. Gudalov, M., \& Gozieva, M. (2020, December). Development Of Tourism In Zaamin National Nature Park By The Cluster Method. In INTERNATIONAL SCIENTIFIC AND CURRENT RESEARCH CONFERENCES (pp. 111-114).

8. Go'dalov, M. R. (2014). Nature of Jizzakh region and its protection.-T.:.". Science and technology.

9. Lapasovich, M. O., Nematovich, N. O., Yakubovich, Z. B., Rustamovich, U. M., \& Tolipov, F. (2020). HISTORICAL AND ETHNOGRAPHIC CHARACTERISTICS AND SOCIO-SPIRITUAL FACTORS OF VISITING TOURISM IN UZBEKISTAN. Journal of Critical Reviews, 7(6), 47-50. 